Original Article

Original Article

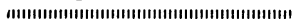

\title{
Metabolism of Cycloprothrin in Rice Plants
}

\author{
Kohichiroh Seguchi, Sinichi Sakai, Hisafumi Kobayasi \\ and Yoshiroh KaTOH \\ Fine Chemicals Group, Agrochemicals Division, Ageo Research Laboratory, \\ Nippon Kayaku Co., Ltd., Koshikiya, Ageo 362, Japan
}

(Received January 23, 1991)

\begin{abstract}
Absorption, translocation and metabolism of an insecticide, cycloprothrin $[(R S)-\alpha-$ cyano-3-phenoxybenzyl (RS)-2,2-dichloro-1-(4-ethoxyphenyl)cyclopropane carboxylate], were examined in rice plants under laboratory conditions. When ${ }^{14} \mathrm{C}$-cycloprothrin was applied to simulated paddy water, the radioactivity in the rice plants in the 3.5-leaf stage increased with time to reach a maximum concentration within 7 days, and this level was retained to the mature stage. At the mature stage, the rice shoots and the hulled grains contained 0.161 and $0.157 \mathrm{ppm}{ }^{14} \mathrm{C}$-cycloprothrin equivalents, respectively. A small amount of unchanged cycloprothrin was found in the shoots but not in the grains. ${ }^{14} \mathrm{C}$-Cycloprothrin topically applied on the leaf surface was not readily translocated to other untreated parts, and $98 \%$ of the applied radioactivity was recovered from the treated parts even after 28 days. When an emulsion of ${ }^{14} \mathrm{C}$-cycloprothrin was applied to rice plants in the heading stage, it adhered to the foliage at $9.33 \mathrm{ppm}$ and the level hardly lowered during the progression to the mature stage. Unchanged cycloprothrin remained in the shoots and hulled grains at 9.452 and $<0.001 \mathrm{ppm}$, respectively. The relative amount of optical isomers of cycloprothrin did not change in the mature shoots after foliar application. Cycloprothrin was metabolized via ester cleavage, hydroxylation at the 4-ethoxy position, decarboxylation, hydrolysis of the $\mathrm{CN}$ group to $\mathrm{CONH}_{2}$ and $\mathrm{COOH}$ groups and conjugation.
\end{abstract}

\section{INTRODUCTION}

Cycloprothrin [Cyclosaal ${ }^{\circledR}(R S)-\alpha$-cyano-3phenoxybenzyl (RS)-2,2-dichloro-1-(4-ethoxyphenyl)cyclopropane carboxylate] is a new type of insecticide with a combined DDTpyrethroid structure, which is used for control of insect pests on paddy rice plants, vegetables and fruit trees. In connection with the practical use of this insecticide, it is important to evaluate its metabolic fate in mammals and in the environment. The metabolism study on cycloprothrin in rats has already been done, ${ }^{1)}$ and this time we studied the absorption, translocation and metabolic fate of cycloprothrin in rice plants. This paper reports the results.

\section{MATERIALS AND METHODS}

\section{Chemicals}

${ }^{14} \mathrm{C}$-Cycloprothrin labeled at the $\mathrm{C}-3$ position of the 2,2-dichlorocyclopropane ring in the acid moiety with a specific radioactivity of $455 \mathrm{MBq} / \mathrm{mmol}$ and a radiochemical purity of more than $99 \%$ was used in the experiments. ${ }^{1)}$ Authentic compounds to identify cycloprothrin metabolites were synthesized in our laboratory. The $R f$ values on silica-gel $60 \mathrm{~F}_{254}$ chromatoplates $(20 \times 20 \mathrm{~cm}, 0.25 \mathrm{~mm}$ thick, Merck, Germany) with several solvent systems and the names or abbreviations of the chemicals are shown in Table 1.

\section{Radioassay}

Liquid scintillation counting (LSC), combustion analysis and radioautography were 
Table 1 Cycloprothrin and its metabolites in rice plants.

\begin{tabular}{|c|c|c|c|c|c|}
\hline \multirow{2}{*}{$\begin{array}{l}\text { Designation } \\
\text { or } \\
\text { Abbreviation }\end{array}$} & \multirow{2}{*}{ Chemical name } & \multicolumn{4}{|c|}{$R f$ values in solvent systems ${ }^{a}$} \\
\hline & & A & $\mathrm{B}$ & $\mathrm{C}$ & $\mathrm{D}$ \\
\hline Cycloprothrin & $\begin{array}{l}(R S) \text { - } \alpha \text {-cyano-3-phenoxybenzyl }(R S) \text { - } \\
\text { 2,2-dichloro-1-(4-ethoxyphenyl) } \\
\text { cyclopropanecarboxylate }\end{array}$ & 0.45 & 0.89 & 0.76 & 0.53 \\
\hline HO-Cycloprothrin & $\begin{array}{l}(R S) \text { - } \alpha \text {-cyano-3-phenoxybenzyl }(R S)- \\
\text { 2,2-dichloro-1-(4-hydroxyphenyl) } \\
\text { cyclopropanecarboxylate }\end{array}$ & 0.21 & 0.72 & 0.50 & 0.20 \\
\hline $\begin{array}{l}\mathrm{CONH}_{2-}^{-} \\
\text {Cycloprothrin }\end{array}$ & $\begin{array}{l}(R S) \text { - } \alpha \text {-aminocarbonyl-3-phenoxybenzyl } \\
(R S)-2,2 \text {-dichloro-1-(4-ethoxyphenyl }) \\
\text { cyclopropanecarboxylate }\end{array}$ & 0.16 & 0.49 & 0.37 & 0.07 \\
\hline $\begin{array}{l}\text { COOH- } \\
\text { Cycloprothrin }\end{array}$ & $\begin{array}{l}(R S) \text { - } \alpha \text {-hydroxycarbonyl-3-phenoxybenzyl } \\
\text { 2,2-dichloro-1 }(R S) \text {-(4-ethoxyphenyl) } \\
\text { cyclopropanecarboxylate }\end{array}$ & 0.09 & 0.40 & 0.38 & 0.11 \\
\hline $\begin{array}{l}\text { HO-phenoxybenzyl } \\
\text { Cycloprothrin }\end{array}$ & $\begin{array}{l}(R S) \text { - } \alpha \text {-cyano-3-(4-hydroxyphenoxy)benzyl } \\
(R S) \text {-2,2-dichloro-1-(4-ethoxyphenyl) } \\
\text { cyclopropanecarboxylate }\end{array}$ & 0.21 & 0.71 & 0.49 & 0.17 \\
\hline $\begin{array}{l}\text { HO-phenyl- } \\
\text { Cycloprothrin }\end{array}$ & $\begin{array}{l}(R S) \text { - } \alpha \text {-cyano-3-hydroxybenzyl } \\
(R S) \text {-2,2-dichloro-1-(4-ethoxyphenyl) } \\
\text { cyclopropanecarboxylate }\end{array}$ & 0.23 & 0.71 & 0.54 & 0.22 \\
\hline $\begin{array}{l}\mathrm{De}-\mathrm{CO}_{2-}^{-} \\
\quad \text { Cycloprothrin }\end{array}$ & $\begin{array}{l}(R S)-1-[(R S)-\alpha \text {-cyano-3-phenoxybenzyl] } \\
\text { 2,2-dichloro-1-(4-ethoxyphenyl)cyclopropane }\end{array}$ & $\begin{array}{l}0.57 \\
0.47\end{array}$ & 0.89 & $\begin{array}{l}0.82 \\
0.77\end{array}$ & $\begin{array}{l}0.62 \\
0.53\end{array}$ \\
\hline $\mathrm{C}_{2} \mathrm{H}_{5} \mathrm{O}$-Acid & $\begin{array}{l}(R S) \text {-2,2-dichloro-1-(4-ethoxyphenyl) } \\
\text { cyclopropanecarboxylic acid }\end{array}$ & 0.24 & 0.52 & 0.52 & 0.29 \\
\hline HO-Acid & $\begin{array}{l}(R S) \text {-2,2-dichloro-1-(4-hydroxyphenyl) } \\
\text { cyclopropanecarboxylic acid }\end{array}$ & 0.10 & 0.37 & 0.38 & 0.12 \\
\hline $\mathrm{HOC}_{2} \mathrm{H}_{4} \mathrm{O}-\mathrm{Acid}$ & $\begin{array}{l}(R S)-2,2 \text {-dichloro-1-[4-(2-hydroxyethoxy)phenyl]- } \\
\text { cyclopropanecarboxylic acid }\end{array}$ & 0.04 & 0.17 & 0.19 & 0.05 \\
\hline
\end{tabular}

a) Solvent systems: A, hexane: acetone (3:1); B, hexane: benzene: ethyl acetate: 2-propanol: acetic acid (100:60:40:10:1); C, hexane: isopropyl ether: acetone: acetic acid (40:40:20:1); D, hexane: ethyl ether: acetic acid $(40: 20: 1)$.

carried out according to the methods reported previously. ${ }^{1)}$

\section{Rice Plants}

Rice plants (Oryza sativa L.) of the Japanese variety "Nihon-bare" were cultivated in Wagner pots (1/5000 a) filled with Ageo soil (clay loam) in a greenhouse in our laboratory. Seedlings in the 3.5-leaf and heading stages were used in the experiments.

\section{Treatment with ${ }^{14} \mathrm{C}$-Cycloprothrin \\ 4.1 Submerged application}

Rice plants in the 3.5-leaf stage in Wagner pots $(1 / 5000 \mathrm{a})$ were selected for the experiment. Granules containing $0.4 \%{ }^{14} \mathrm{C}$-cycloprothrin were prepared and applied to paddy water $4 \mathrm{~cm}$ deep at a rate of $200 \mathrm{mg}(925 \mathrm{kBq})$ per pot. The plants were harvested at intervals and divided into roots and shoots. The mature plants were divided into hulled grains, hulls, roots and shoots.

\subsection{Topical application}

An aliquot of $1000 \mathrm{ppm}$ water emulsion of ${ }^{14} \mathrm{C}$-cycloprothrin was applied to the center of the third leaf : at the 3.5-leaf stage with a microsyringe at a rate of $1.5 \mu \mathrm{g} / \mathrm{cm}^{2} \quad(1.48$ $\left.\mathrm{kBq} / \mathrm{cm}^{2}\right)$. At intervals, plants were harvested and divided into the applied part and others.

\subsection{Foliar application}

Ten milliliters of $160 \mathrm{ppm}$ water emulsion of ${ }^{14} \mathrm{C}$-cycloprothrin was sprayed onto rice plants in the heading stage in Wagner pots $(1 / 5000 \mathrm{a})$. This dose was calculated from the practical application rate of $80 \mathrm{~g}$ of active ingredient/ha in the field. The plants were harvested at intervals.

\section{Treatment of Soils}

Aichi clay loam and Chiba sandy clay loam soils were used. Each soil equivalent to 39.2 
$\mathrm{g}$ on a dry weight basis was placed in a 200 $\mathrm{ml}$ Erlenmeyer flask and water was added up to $2 \mathrm{~cm}$ from the bottom to simulate a flooded condition. The soils were incubated at $30^{\circ} \mathrm{C}$ in the dark for a week. After the preincubation, $39.2 \mu \mathrm{g}$ of ${ }^{14} \mathrm{C}$-cycloprothrin $(37 \mathrm{kBq})$ in $0.1 \mathrm{ml}$ of acetonitrile was added to each soil. The dose corresponded to $1 \mathrm{ppm}$ cycloprothrin on a dry soil basis. The treated soils were incubated at $30^{\circ} \mathrm{C}$ in the dark. The evolved ${ }^{14} \mathrm{CO}_{2}$ was collected in $10 \% \mathrm{NaOH}$ solution $(50 \mathrm{ml})$ after purging the flask with $\mathrm{CO}_{2-}$ free air. At intervals, a sample of each treated soil was extracted with acetonitrile. The extracts were concentrated in vacuo and then partitioned into ethyl acetate.

\section{Fractionation of the Radioactivity}

Plant samples were cut into small pieces and homogenized in acetonitrile with a Polytron ${ }^{\circledR}$ (Kinematica, Switzerland). The homogenate was extracted with acetonitrile and acetonitrile-water $(2: 1)$. The extracts were combined, concentrated in vacuo and partitioned between ethyl acetate and water ( $\mathrm{pH} 3)$. The amount of radioactivity in the ethyl acetate layer, the aqueous layer and the residues was measured. The ethyl acetate layer was concentrated and separated by TLC. A part of the aqueous layer was lyophilized to dryness. The residues and the origin of the TLC plates (silica-gel $60 \mathrm{~F}_{254}, 0.25 \mathrm{~mm}$ thick, Merck) were extracted with methanol. The methanol extract was treated with $\beta$-glucosidase (Sigma) and cellulase (Sigma) in $0.1 \mathrm{~m}$ sodium acetate buffer $(\mathrm{pH} 4.8) .{ }^{2)}$ After incubation at $37^{\circ} \mathrm{C}$ for $24 \mathrm{hr}$, the reaction mixture was adjusted to $\mathrm{pH} 3$ with $\mathrm{HCl}$ and extracted with ethyl acetate. Radioactive metabolites in the extracts were detected and identified by cochromatography with authentic samples on TLC, and the radioactivity was measured with a liquid scintillation counter.

\section{Determination of Optical Isomers of Cyclo- prothrin}

The ethyl acetate extract from the shoots was mixed with unlabeled cycloprothrin as a carrier and poured onto a silica-gel column for cleanup. A mixture of radioactive and nonradioactive cycloprothrin was eluted with hexane-ethyl acetate $(9: 1)$ from the column. The effluent was treated with $l$-menthol in $\mathrm{HCl}$ by heating and converted into $\alpha-1$-menthyloxycarbonyl-3-phenoxybenzyl $(R S)$-2,2-dichloro-1-(4-ethoxyphenyl)cyclopropane carboxylate according to the method of Horiba et al. ${ }^{3)}$ The obtained diastereoisomeric mixture was analyzed by high-performance liquid chromatography on an instrument (Shimadzu LC-6A) equipped with an ultraviolet detector operating at $254 \mathrm{~nm}$ and a radio analyzer (Aloka RLC-551) (A. Kurozumi: unpublished data). The operating conditions: column, RADIAL-PAC(A) Silica pressurized with Ztype Pressurized Module (RCSS, Waters Co.); mobile phase, hexane-isopropyl ether-ethyl acetate $(100: 3: 1, \mathrm{v} / \mathrm{v})$; flow rate, $1.5 \mathrm{ml} / \mathrm{min}$.

\section{RESULTS}

\section{Absorption and Translocation of ${ }^{14} \mathrm{C}-\mathrm{Cyclo}$ - prothrin in Rice Plants}

When ${ }^{14} \mathrm{C}$-cycloprothrin was topically applied to the third leaves of rice plants in the 3.5-leaf stage, the recovery of total radiocarbon decreased only slightly with time, as shown in Table 2. After 28 days, $98.7 \%$ of the applied radioactivity was recovered from the plants. Most of the recovered radioactivity was present in the treated leaves, only $0.08 \%$ of the applied radioactivity in the other parts.

Table 2 Translocation of radioactivity in rice plants after topical application on the leaf surface.

\begin{tabular}{llcccc}
\hline & & & \multicolumn{3}{c}{$\begin{array}{c}\text { \% of applied } \\
\text { radioactivity }\end{array}$} \\
\cline { 3 - 6 } \multicolumn{1}{c}{ Plant parts } & & \multicolumn{4}{c}{$\begin{array}{c}\text { Days after } \\
\text { application }\end{array}$} \\
\cline { 3 - 6 } & & & 7 & 14 & 28 \\
\hline Treated leaf & Applied part & 102 & 104 & 98.4 \\
(Third leaf) & Upper & part & 0.02 & 0.05 & 0.15 \\
& Lower & part & 0.02 & 0.03 & 0.09 \\
\hline Untreated & Fifth leaf & & 0.01 & 0.02 \\
leaves & Fourth leaf & $<0.01$ & 0.01 & 0.01 \\
& Second leaf & $<0.01$ & $<0.01$ & 0.01 \\
\hline Sheath & & & 0.01 & 0.01 & 0.04 \\
\hline Total & & & 102 & 104 & 98.7 \\
\hline
\end{tabular}


Table 3 Absorption and translocation of radioactivity in rice plants after submerged application.

\begin{tabular}{|c|c|c|c|c|c|c|}
\hline \multirow{3}{*}{$\begin{array}{l}\text { Plant } \\
\text { parts }\end{array}$} & \multirow{3}{*}{ Fractions } & \multicolumn{5}{|c|}{$\mu \mathrm{g}{ }^{14} \mathrm{C}$-cycloprothrin Eq/g (undried weight) } \\
\hline & & \multicolumn{5}{|c|}{ Days after application } \\
\hline & & 7 & 14 & 28 & 56 & 132 \\
\hline \multirow[t]{4}{*}{ Shoot } & Cycloprothrin & 0.102 & 0.057 & 0.035 & 0.008 & 0.049 \\
\hline & Others & 0.007 & 0.008 & 0.028 & 0.024 & 0.028 \\
\hline & Unextractable residues & 0.004 & 0.007 & 0.023 & 0.062 & 0.084 \\
\hline & Total & 0.113 & 0.072 & 0.086 & 0.092 & 0.161 \\
\hline \multirow[t]{4}{*}{ Root } & Cycloprothrin & 0.131 & 0.291 & 0.066 & 0.076 & 0.274 \\
\hline & Others & 0.003 & 0.047 & 0.026 & 0.052 & 0.193 \\
\hline & Unextractable residues & 0.003 & 0.063 & 0.042 & 0.089 & 0.421 \\
\hline & Total & 0.137 & 0.401 & 0.134 & 0.217 & 0.888 \\
\hline
\end{tabular}

Table 4 Amount of residual radioactivity in whole rice plants after foliar application at the heading stage.

\begin{tabular}{|c|c|c|c|c|}
\hline \multirow{3}{*}{ Fractions } & \multicolumn{4}{|c|}{ Days after application } \\
\hline & 0 & 7 & 14 & 51 \\
\hline & $\mu \mathrm{g} / \mathrm{g}^{\mathrm{a})}(\mu \mathrm{g} / \mathrm{p})^{\mathrm{b})}$ & $\mu \mathrm{g} / \mathrm{g}(\mu \mathrm{g} / \mathrm{p})$ & $\mu \mathrm{g} / \mathrm{g}(\mu \mathrm{g} / \mathrm{p})$ & $\mu \mathrm{g} / \mathrm{g}(\mu \mathrm{g} / \mathrm{p})$ \\
\hline Cycloprothrin & $9.33(377$ & $7.22(333)$ & $5.82(299)$ & $7.09(296 \quad)$ \\
\hline Others & $0.14(5.65)$ & $0.30(13.8)$ & $0.36(18.5)$ & $0.83(34.6)$ \\
\hline $\begin{array}{l}\text { Unextractable } \\
\text { residues }\end{array}$ & $0.02(0.81)$ & $0.03(1.38)$ & $0.04(2.05)$ & $0.30(12.5)$ \\
\hline Total & $9.49(383$ & $7.55(348$ & $6.22(320$ & $8.22(343)$ \\
\hline
\end{tabular}

a) $\mu \mathrm{g}{ }^{14} \mathrm{C}$-cycloprothrin Eq/g (undried weight).

b) $\mu \mathrm{g}{ }^{14} \mathrm{C}$-cycloprothrin Eq/whole plant.

By submerged application, the radioactivity was absorbed into the stems and the roots, and translocated to the upper parts of the plants. Table 3 shows the absorption and translocation patterns of the radioactivity derived from ${ }^{14} \mathrm{C}$-cycloprothrin applied to the paddy water. Radioactivity concentration in the shoots reached a plateau within 7 days after treatment and tended to decrease slightly thereafter. Radioactivity levels in the shoots were 0.113 and $0.092 \mathrm{ppm}$ cycloprothrin equivalent 7 and 56 days after treatment, respectively. At the mature stage, $0.157,0.417$ and 0.161 ppm cycloprothrin equivalents of radioactivity were present in the hulled grains, hull and the shoots, respectively. The ratios of ${ }^{14} \mathrm{C}$-cycloprothrin to total radioactivity in the shoots after 7 and 56 days were 90 and 9\%, respectively. The acetonitrile-water extractable metabolites reached a maximum 28 days after treatment and remained almost constant thereafter. The bound radioactivity, however, increased at the mature stage. Radiocarbon concentration in roots was relatively high $(0.888 \mathrm{ppm})$ at the mature stage. The radioactivity ratio in the roots was $31 \%$ for ${ }^{14} \mathrm{C}$-cycloprothrin and $47 \%$ for unextractable residues.

\section{Persistence of ${ }^{14} \mathrm{C}$-Cycloprothrin in Rice Plants}

Changes in the levels of ${ }^{14} \mathrm{C}$-cycloprothrin and its metabolites residues in rice plants after foliar application at the heading stage are 
Table 5 Distribution of radioactivity in mature rice plant after submerged or foliar application.

\begin{tabular}{|c|c|c|c|c|c|}
\hline \multirow{2}{*}{$\begin{array}{l}\text { Plant } \\
\text { parts }\end{array}$} & \multirow{2}{*}{ Fraction } & \multicolumn{2}{|c|}{ Submerged application } & \multicolumn{2}{|c|}{ Foliar application } \\
\hline & & $\mu \mathrm{g} / \mathrm{g}^{\mathrm{a})}$ & $\%{ }^{b)}$ & $\mu \mathrm{g} / \mathrm{g}$ & $\%$ \\
\hline \multirow[t]{4}{*}{ Hulled grain } & Cycloprothrin & $<0.001$ & & $<0.001$ & \\
\hline & Others & 0.004 & & 0.005 & \\
\hline & Unextractable residues & 0.152 & & 0.026 & \\
\hline & Total & 0.157 & 6.30 & 0.031 & 0.07 \\
\hline \multirow[t]{4}{*}{ Hull } & Cycloprothrin & & & 3.773 & \\
\hline & Others & & & 0.647 & \\
\hline & Unextractable residues & & & 0.397 & \\
\hline & Total & 0.417 & 2.19 & 4.817 & 5.11 \\
\hline \multirow[t]{4}{*}{ Shoot } & Cycloprothrin & 0.049 & & 9.452 & \\
\hline & Others & 0.028 & & 1.078 & \\
\hline & Unextractable residues & 0.084 & & 0.359 & \\
\hline & Total & 0.161 & 30.0 & 10.89 & 94.8 \\
\hline \multirow[t]{4}{*}{ Root } & Cycloprothrin & 0.274 & & & \\
\hline & Others & 0.193 & & & \\
\hline & Unextractable residues & 0.421 & & & \\
\hline & Total & 0.888 & 61.0 & & \\
\hline
\end{tabular}

a) Values are expressed by $\mu \mathrm{g}{ }^{14} \mathrm{C}$-cycloprothrin Eq/g (undried weight).

b) Values are expressed as $\%$ of radioactivity of each part with respect to total radioactivity in the plant.

Table 6 Proportions of the four optical isomers in applied and residual cycloprothrin.

\begin{tabular}{lcccc}
\hline & \multicolumn{4}{c}{ Isomer ratios (\%) } \\
\cline { 2 - 5 } & A & B & C & D \\
\hline Applied cycloprothrin & 25.8 & 22.5 & 27.1 & 24.6 \\
Residual cycloprothrin & 27.7 & 25.1 & 25.1 & 22.1 \\
\hline
\end{tabular}

shown in Table 4. When a $160 \mathrm{ppm}$ water emulsion of ${ }^{14} \mathrm{C}$-cycloprothrin was sprayed on rice plants, ${ }^{14} \mathrm{C}$-cycloprothrin remained at 9.33 ppm in the whole plants. During the following 2 weeks, the residual concentration decreased to $79 \%$ of the initial levels, but did not decrease further towards the mature stage. Nearly $95 \%$ of the radioactivity in the plants in the mature stage was located in the shoots as shown in Table 5 . The remaining radioactivity was $5.11 \%$ in the hulls and $0.07 \%$ in hulled grains.

\section{Analysis of Cycloprothrin Stereoisomers in Rice Plants}

Optically active derivatives of the four isomers were completely separated by HPLC within 20 minutes and eluted in the order shown in Fig. 1. Table 6 shows the proportions of the four optical isomers in the applied and residual cycloprothrin in the shoots 51 days after foliar application. The relative amounts of cycloprothrin isomers $\mathrm{A}, \mathrm{B}, \mathrm{C}$, and $\mathrm{D}$ prior to the treatment were $25.8 \%, 22.5 \%$, $27.1 \%$ and $24.6 \%$, respectively. Fifty-one days after foliar application, the amount of residual ${ }^{14} \mathrm{C}$-cycloprothrin in the shoots decreased to $78 \%$, but there was no change in the abundance ratio.

\section{Metabolism of ${ }^{14} \mathrm{C}$-Cycloprothrin in Rice Plants}

Plant metabolites at the mature stage were analyzed. The metabolites identified by twodimensional co-TLC and their abundance in the 


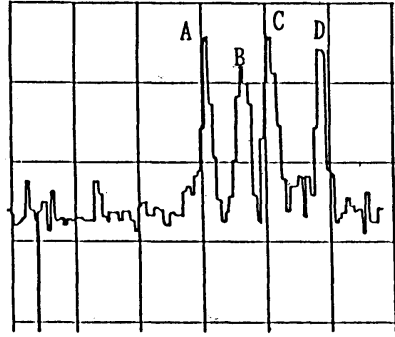

RI Detection

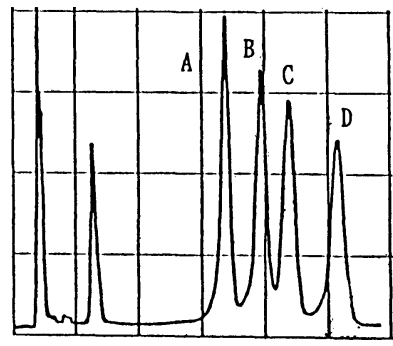

UV Detection

Fig. 1 HPLC chromatogram of $l$-menthyl ester derivative of racemic cycloprothrin.

A : $(R)$ - $\alpha$-cyano-3-phenoxybenzyl (S)-2,2-dichloro-1-(4-ethoxyphenyl) cyclopropanecarboxylate.

B: $(R)$ - $\alpha$-cyano-3-phenoxybenzyl $(R)$-2,2-dichloro-1-(4-ethoxyphenyl) cyclopropanecarboxylate.

C: $(S)$ - $\alpha$-cyano-3-phenoxybenzyl $(R)$-2,2-dichloro-1-(4-ethoxyphenyl) cyclopropanecarboxylate.

D: $(S)$ - $\alpha$-cyano-3-phenoxybenzyl (S)-2,2-dichloro-1-(4-ethoxyphenyl) cyclopropanecarboxylate.

HPLC conditions: column, RADIAKL-PAC(A) Silica; mobile phase, hexane-isopropyl ether-ethyl

acetate $(100: 3: 1, \mathrm{v} / \mathrm{v})$ at a flow rate of $1.5 \mathrm{ml} / \mathrm{min}$; ultraviolet detection wavelength, $254 \mathrm{~nm}$.

Table 7 Cycloprothrin and its metabolites in rice plants after submerged or foliar application.

\begin{tabular}{|c|c|c|c|c|c|}
\hline \multirow{3}{*}{\multicolumn{2}{|c|}{$\begin{array}{l}\text { Cycloprothrin } \\
\text { and } \\
\text { metabolites }\end{array}$}} & \multicolumn{4}{|c|}{$\mu \mathrm{g}{ }^{14} \mathrm{C}$-cycloprothrin Eq/g (undried weight) } \\
\hline & & \multirow{2}{*}{$\begin{array}{c}28 \text { days after } \\
\text { Submerged application } \\
\text { Shoot }^{\mathrm{a}}\end{array}$} & \multicolumn{3}{|c|}{$\begin{array}{l}51 \text { days after } \\
\text { Foliar application }\end{array}$} \\
\hline & & & Grain ${ }^{a}$ & Hulla) & Shoot \\
\hline \multicolumn{2}{|l|}{ Cycloprothrin } & 0.035 & & 3.773 & 9.452 \\
\hline \multicolumn{2}{|c|}{ HO-Cycloprothrin } & 0.001 & & 0.040 & 0.118 \\
\hline \multicolumn{2}{|c|}{$\mathrm{CONH}_{2}$-Cycloprothrin } & & & & 0.032 \\
\hline \multicolumn{2}{|c|}{$\mathrm{COOH}-\mathrm{Cycloprothrin}$} & & & & 0.014 \\
\hline \multicolumn{2}{|c|}{ De- $\mathrm{CO}_{2}$ Cycloprothrin } & & & & 0.078 \\
\hline \multicolumn{2}{|l|}{$\mathrm{C}_{2} \mathrm{H}_{5} \mathrm{O}$-Acid } & 0.008 & & 0.220 & 0.286 \\
\hline \multirow[t]{2}{*}{ HO-Acid } & Free & 0.003 & & & 0.082 \\
\hline & Conj. & & & & 0.197 \\
\hline \multirow[t]{2}{*}{$\mathrm{HOC}_{2} \mathrm{H}_{4} \mathrm{O}-$ Acid } & Free & & & & 0.008 \\
\hline & Conj. & & & & 0.006 \\
\hline \multicolumn{2}{|l|}{ Others } & 0.016 & 0.005 & 0.387 & 0.267 \\
\hline \multicolumn{2}{|c|}{ Unextractable residues } & 0.023 & 0.026 & 0.397 & 0.359 \\
\hline
\end{tabular}

a) Untreated enzyme.

extracts are shown in Table 7 . On the 5lst day after rice plants were treated with ${ }^{14} \mathrm{C}$ cycloprothrin on the leaves, seven metabolites, $(R S)$ - $\alpha$-cyano-3-phenoxybenzyl $(R S)$ 2,2-dichloro-1-(4-hydroxyphenyl)cyclopropanecarboxylate (HO-cycloprothrin), (RS)- $\alpha$-aminocarbonyl-3-phenoxybenzyl (RS)-2, 2-dichloro1 - (4 - ethoxyphenyl) cyclopropanecarboxylate (CONH${ }_{2}$-cycloprothrin), (RS)- $\alpha$-hydroxycarbonyl - 3 - phenoxybenzyl (RS) - 2, 2 - dichloro1 - (4 - ethoxyphenyl) cyclopropanecarboxylate
(COOH-cycloprothrin), (RS)-1-[(RS)- $\alpha$-cyano3-phenoxybenzyl] 2,2-dichloro-1-(4-ethoxyphenyl)cyclopropane (De- $\mathrm{CO}_{2}$-cycloprothrin), $(R S)$-2, 2-dichloro-1-(4-ethoxyphenyl)cyclopropanecarboxylic acid $\left(\mathrm{C}_{2} \mathrm{H}_{5} \mathrm{O}\right.$-acid), (RS)-2,2dichloro- 1-(4-hydroxyphenyl) cyclopropanecarboxylic acid (HO-acid) and ( $R S)$-2,2-dichloro1- [4- (2 - hydroxyethoxy) phenyl] cyclopropanecarboxylic acid $\left(\mathrm{HOC}_{2} \mathrm{H}_{4} \mathrm{O}\right.$-acid), were found in the shoots, but only two, HO-cycloprothrin and $\mathrm{C}_{2} \mathrm{H}_{5} \mathrm{O}$-acid, in the hulls. These metabolites 
could not be confirmed in the hulled grains owing to their small amount. In the shoots, $86.7 \%$ of the radioactivity was present as parent compound, $7.5 \%$ being identified metabolites, $2.5 \%$ extractable unknown metabolites and $3.3 \%$ unextractable residues. The major metabolites in the shoots were $\mathrm{C}_{2} \mathrm{H}_{5} \mathrm{O}$ acid and conjugated $\mathrm{HO}$-acid.

On the 28th day after the submerged application of ${ }^{14} \mathrm{C}$-cycloprothrin to rice plants, the shoots contained radioactivity equivalent to $0.086 \mathrm{ppm}$ cycloprothrin. ${ }^{14} \mathrm{C}$-Cycloprothrin accounted for $40.7 \%$ of the radioactivity in the shoots. The other radioactivity in the shoots was $14.0 \%$ in the ethyl acetate extract fraction, $18.6 \%$ in the water-soluble fraction and $26.7 \%$ in the unextractable residues. The ethyl acetate extract fraction contained HOcycloprothrin, $\mathrm{C}_{2} \mathrm{H}_{5} \mathrm{O}$-acid and $\mathrm{HO}$-acid.

\section{Degradation of ${ }^{14} \mathrm{C}$-Cycloprothrin in Flooded Soils}

The degradation of ${ }^{14} \mathrm{C}$-cycloprothrin in flooded soils is shown in Table $8 .{ }^{14} \mathrm{C}$-Cycloprothrin degraded in flooded soil with an initial half-life of about 61 days in Aichi soil and about 33 days in Chiba soil. In contrast, the amounts of ${ }^{14} \mathrm{CO}_{2}$ evolved and bound radioactivity increased with time. After 24 weeks, ${ }^{14} \mathrm{CO}_{2}$ evolved from the Aichi and Chiba soils amounted to $25.0 \%$ and $43.7 \%$ of the applied radioactivity, respectively. The bound radioactivity in the Chiba soil reached its maximum amount after 16 weeks. At least seven degradation products were identified in the flooded soils. There was no difference in degradation pattern between the Aichi and Chiba soils. The major degradation product in the soils was $\mathrm{C}_{2} \mathrm{H}_{5} \mathrm{O}$-acid, which amounted to $19.9 \%$ of the applied radioactivity after 16 weeks in the Aichi soil and $29.8 \%$ after 4 weeks in the Chiba soil. $\mathrm{C}_{2} \mathrm{H}_{5} \mathrm{O}$-Acid subsequently degraded further.

\section{DISCUSSION}

When ${ }^{14} \mathrm{C}$-cycloprothrin was applied into paddy water, radioactivity concentration in rice shoots reached a plateau within 7 days after treatment and tended to decrease slightly thereafter. The ratio of ${ }^{14} \mathrm{C}$-cycloprothrin to total radioactivity in the shoots decreased after 7 days. The bound radioactivity increased at the mature stage, however. In soils under flooded conditions, ${ }^{14} \mathrm{C}$-cycloprothrin was relatively stable and more than $50 \%$ of the parent compound still remained on the 28th day after treatment. This suggests that most of the radioactivity detected in the shoots was due to the movement of ${ }^{14} \mathrm{C}$-cycloprothrin on the shoot surface by capillary action and the absorption of radioactivity still dissolved in the paddy water. Furthermore,

Table 8 Degradation of cycloprothrin in flooded soils.

\begin{tabular}{|c|c|c|c|c|c|c|}
\hline & \multicolumn{6}{|c|}{$\%$ of the applied radioactivity } \\
\hline & \multicolumn{3}{|c|}{$\begin{array}{c}\text { Aichi soil } \\
\text { Weeks after application }\end{array}$} & \multicolumn{3}{|c|}{$\begin{array}{c}\text { Chiba soil } \\
\text { Weeks after application }\end{array}$} \\
\hline & 4 & 16 & 24 & 4 & 16 & 24 \\
\hline Cycloprothrin & 67.3 & 36.4 & 24.2 & 51.7 & 20.6 & 13.8 \\
\hline $\mathrm{CONH}_{2}$-Cycloprothrin & 1.6 & 2.7 & 2.8 & 0.8 & 0.8 & 0.7 \\
\hline $\mathrm{COOH}$-Cycloprothrin & 0.1 & 0.8 & 0.4 & 0.1 & 0.1 & 0.1 \\
\hline $\mathrm{C}_{2} \mathrm{H}_{5} \mathrm{O}$-Acid & 14.0 & 19.9 & 8.1 & 29.8 & 4.0 & 0.6 \\
\hline HO-Acid & 0.7 & & 1.8 & 0.6 & & \\
\hline Mixtures & 1.0 & 0.8 & 0.5 & 0.7 & 0.7 & 0.5 \\
\hline Others & 3.5 & 7.0 & 5.8 & 3.0 & 4.9 & 1.3 \\
\hline Unextractable residues & 5.5 & 14.2 & 27.7 & 4.0 & 28.2 & 28.3 \\
\hline $\mathrm{CO}_{2}$ & 2.2 & 18.0 & 25.0 & 5.0 & 27.2 & 43.7 \\
\hline Total & 95.9 & 99.8 & 96.3 & 95.7 & 86.5 & 89.0 \\
\hline
\end{tabular}

Mixture: HO-cycloprothrin + HO-phenoxybenzylcycloprothrin + HO-phenylcycloprothrin. 
availability to rice plants of ${ }^{14} \mathrm{C}$-cycloprothrin adsorbed on soil particles was very poor, and the transport of ${ }^{14} \mathrm{C}$-cycloprothrin and/or its metabolites from the roots to the shoots and the grains was limited. As a result, radioactivity concentration in the grains was low.

After foliar treatment, disappearance of ${ }^{14} \mathrm{C}$ cycloprothrin from the rice plants was very slow. Seventy-eight percent of the administered ${ }^{14} \mathrm{C}$-cycloprothrin was recovered unchanged from the mature whole rice plants (51 days after treatment). On topical application of ${ }^{14} \mathrm{C}$-cycloprothrin to the leaf surface, the translocation of radioactivity to the untreated parts was very slight. Under greenhouse conditions, phenothrin disappeared from rice plants with a half-life of less than one day. ${ }^{4)}$ Ethofenprox decreased to $10 \%$ of the applied radioactivity in about 20 days on rice leaves. ${ }^{5)}$ Cycloprothrin appears to degrade in rice plants more slowly than other pyrethroids with a 3-phenoxybenzyl moiety. However, under field conditions, disappearance of cycloprothrin from rice plants may be accelerated by such physicochemical factors as wind, sunlight and rainfall.

The metabolic behavior of cycloprothrin in the rice plants after foliar or submerged application is summarized in Fig. 2. Seven different metabolites were identified. Main metabolites were $\mathrm{C}_{2} \mathrm{H}_{5} \mathrm{O}$-acid, $\mathrm{HO}$-acid and HO-cycloprothrin. They were also main me-

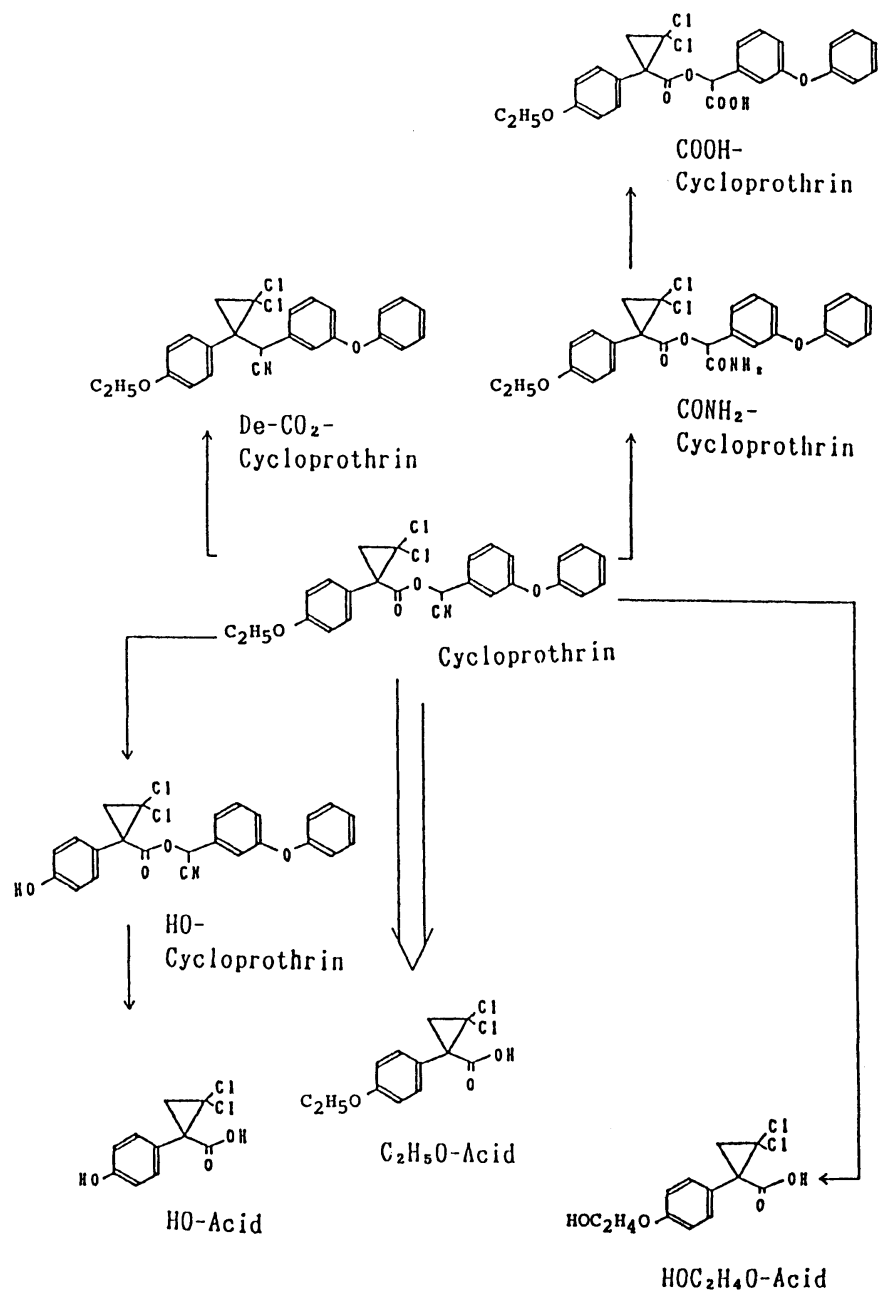

Fig. 2 Proposed metabolic pathways for cycloprothrin in rice plants. 
tabolites in rats. ${ }^{1)}$ This therefore suggested that major metabolic pathways of cycloprothrin are hydrolysis and oxidation in plants as well. On the other hand, De- $\mathrm{CO}_{2-}, \mathrm{CONH}_{2-}$ and $\mathrm{COOH}$-cycloprothrin were minor metabolites, which were not identified in rats. $\mathrm{CONH}_{2-}$ and $\mathrm{COOH}$-cycloprothrin were also found in soils under flooded conditions. De$\mathrm{CO}_{2}$-cycloprothrin was considered to be a product of photodecomposition on the leaf surface. $\mathrm{CONH}_{2-}$ and $\mathrm{COOH}$-cycloprothrin appear to be produced in part via photochemical and/or other physicochemical reactions. Such decarboxylation and hydrolysis of the $\mathrm{CN}$ group to $\mathrm{CONH}_{2}$ and $\mathrm{COOH}$ groups were also observed with fenvalerate. ${ }^{6)}$ The hulled grains contained a small amount of radioactivity, but neither cycloprothrin nor its metabolites were identified.

Cycloprothrin is a mixture of four stereoisomeric esters; it has two asymmetric carbons in the acid and alcohol moieties. In the experiment to determine optical isomers, the total amount of unmetabolized cycloprothrin in the shoots decreased by $22 \%$, but the abundance ratio did not change. This suggests that there is no stereospecificity in the metabolism of cycloprothrin in rice plants.

\section{ACKNOWLEDGMENTS}

We thank our colleagues of Agrochemicals Division of Nippon Kayaku Co., Ltd. for providing authentic compounds and for their valuable advice and assistance during the course of this study.

\section{REFERENCES}

1) K. Seguchi, S. Asaka, Y. Katoh \& I. Yamaguchi: J. Pesticide Sci. 16, 591 (1991)

2) "Radioisotope-Method of Drug Metabolism Studies," ed. by Japan Radioisotope Association, Maruzen, Tokyo, 1981 (in Japanese)

3) M. Horiba, H. Kitahara, S. Yamamoto \& A. Murano: Agric. Biol. Chem. 44, 1361 (1980)
4) K. Nambu, H. Ohkawa \& J. Miyamoto: J. Pesticide Sci. 5, 177 (1980)

5) K. Ohnuma, T. Imai, S. Arai, K. Oda, K. Tomoda \& K. Kitajima: Abstr. 13th Annual Meeting of Pesticide Sci. Soc. Japan, p. 90, 1988

6) H. Ohkawa, K. Nambu \& J. Miyamoto: J. Pesticide Sci. 5, 215 (1980)

\section{要約}

\section{シクロプロトリンのイネにおける代謝}

瀬口宏一郎，堺 信一，小林久文，加藤義郎 シクロプロトリンは水稲, 野菜, 果樹等の害虫を防除 するために開発された殺虫剂である.Cyclopropane 環の 3 位を ${ }^{14} \mathrm{C}$ で標識したシクロプロトリンを用いて，イネ における吸収移行および代謝について検討した。 ${ }^{14} \mathrm{C}$-シ クロプロトリンを水面処理すると， 3.5 葉期におけるイ ネ体の放射能濃度は 7 日まで経時的に増加し, 以後ほぼ 同濃度で推移した。 処理 132 日後の茎葉と玄米には ${ }^{14} \mathrm{C}$ シクロプロトリン換算で $0.161 \mathrm{ppm}$ と $0.157 \mathrm{ppm}$ 相当 の放射能が移行残留した. 茎葉から末変化のシクロプロ トリンが微量検出されたが, 玄米からは検出されなかっ た、イネの葉面に塗布した ${ }^{14} \mathrm{C}$-シクロプロトリンはほ とんど浸透移行せず，塗布 28 日後においても処理放射 能の $98 \%$ が塗布部位に残留した.出穂期のイネに茎葉 散布した ${ }^{14} \mathrm{C}$-シクロプロトリンも同様な挙動を示し, 玄 米への放射能の移行は非常に少なかった。散布直後植物 体全体に $9.33 \mathrm{ppm}$ の ${ }^{14} \mathrm{C}$-シクロプロトリンが付着し た. 51 日後の収穫時, 茎葉に残留した ${ }^{14} \mathrm{C}$-シクロプロ トリンは $9.454 \mathrm{ppm}$ であり，玄米は $0.001 \mathrm{ppm}$ 以下で あった. 散布 51 日後茎葉に残留したシクロプロトリン の 4 種立体異性体の存在比に変化は認められなかった. イネ体から 7 種の代謝物が検出され, 主代謝物は $(R S)$ 2, 2-dichloro-1-(4-ethoxyphenyl)cyclopropanecarboxylic acid, (RS) - 2, 2-dichloro-1 - (4-hydroxyphenyl) cyclopropanecarboxylic acid, $(R S)$ - $\alpha$-cyano-3-phenoxybenzyl $(R S)$ 2,2 - dichloro- 1 -(4-hydroxyphenyl)cyclopropranecarboxylate および $(R S)-1-[(R S)$ - $\alpha$-cyano-3-phenoxybenzyl]2, 2 dichloro-1-(4-ethoxyphenyl)cyclopropane であった. 